\title{
D1-D2 Interaction in Feedback Control of Midbrain Dopamine Neurons
}

\author{
Wei-Xing Shi, Paula L. Smith, Chen-Lun Pun, Barbara Millet, and Benjamin S. Bunney \\ Department of Psychiatry, Yale University School of Medicine, New Haven, Connecticut 06510
}

Dopamine (DA) D1-like receptors are present in pathways implicated in feedback control of midbrain DA neurons. However, stimulation of these receptors either produces no effect on DA cells, or the effect is inconsistent. It is possible that the expression of a D1 feedback effect requires co-activation of D2-like receptors. To test this hypothesis, we recorded extracellularly the spontaneous activity of nigral DA cells in a low cerveau isolé rat preparation. SKF38393 and dyhydrexidine, two D1 agonists, were administered systemically to animals pretreated with different doses of the D2 agonist quinpirole. Supporting the hypothesis, the two D1 agonists consistently inhibited DA cells in animals given high doses of quinpirole ( $\geq 40 \mu \mathrm{g} / \mathrm{kg}$, i.v.). However, no significant D1 effect was observed in animals pretreated with only low doses $(\leq 20 \mu \mathrm{g} / \mathrm{kg}$ ) of quinpirole. Because low doses of D2 agonists preferentially act on DA autorecep- tors, and because the D1 inhibition persisted in animals whose DA autoreceptors were blocked by intranigral application of raclopride, our results suggest that the expression of D1 feedback inhibition requires co-activation of D2-like receptors on DA target neurons, instead of DA neurons themselves. These results, together with the finding that chloral hydrate completely blocked the D1 inhibition, may explain why previous studies have failed to show a consistent D1 effect on DA cells and suggest that drugs designed to act specifically on one subtype of DA receptor may, via feedback pathways, influence the action of endogenous DA on other DA receptor subtypes as well.

Key words: DA neuron; feedback pathway; D1; D2; synergistic; SKF38393; dyhydrexidine; substantia nigra; striatonigral; single-unit recording
The activity of midbrain DA neurons is regulated by short and long feedback pathways. The short feedback pathways, mediated by inhibitory D2-like autoreceptors, have been studied extensively. Little is known, however, about the long feedback pathways. By definition, the long feedback pathways involve DA receptors located on neurons postsynaptic to DA terminals. For substantia nigra (SN) DA cells, one such pathway may involve striatonigral GABAergic neurons. These neurons receive direct synaptic input from DA terminals (Freund et al., 1984; Caille et al., 1996) and project to the SN (Bunney and Aghajanian, 1976a), where their terminals make direct synaptic connections with DA cells (Nitsch and Riesenberg, 1988; Bolam and Smith, 1990; Yung et al., 1995; Caille et al., 1996). Consistent with the presence of the striatonigral feedback pathway, the GABA antagonist picrotoxin has been shown to block the inhibition of SN DA neurons induced by the indirect DA agonist amphetamine, and lesions of the striatonigral pathway attenuate the ability of amphetamine to inhibit DA neurons (Bunney and Aghajanian, 1976b, 1978).

However, despite the evidence for their presence, the way long feedback pathways operate is still controversial. One issue concerns the role of D1-like receptors. According to anatomical studies, D1-like receptors should play a major role in the stria-

Received April 21, 1997; revised July 22, 1997; accepted July 30, 1997.

This work was supported in part by the Schizophrenia Research Program of the Scottish Rite Benevolent Foundation (W-X.S.), a NASARD Young Investigator Award (W.-X.S.), the Stanley Foundation for Research on the Mentally Ill (B.S.B), United States Public Health Service Grants MH52686 (W.-X.S.) and MH28849 (B.S.B), and the State of Connecticut. We thank Interneuron Pharmaceuticals, Schering-Plough, Astra, Eli Lilly, and McNeil Pharmaceuticals for their generous supply of DHX, SCH39166, raclopride, quinpirole, and haloperidol, respectively.

Correspondence should be addressed to Dr. Wei-Xing Shi, Department of Psy-

chiatry, Yale University School of Medicine, 333 Cedar Street, SHM B-272, New

Haven, CT 06510.

Copyright (C) 1997 Society for Neuroscience $0270-6474 / 97 / 177988-07 \$ 05.00 / 0$ tonigral pathway because they are the main DA receptors expressed in striatonigral neurons (Yung et al., 1995). Electrophysiologically, however, only D2-like receptor agonists have been shown to have an effect on DA cells. Selective activation of D1-like receptors produces either an inconsistent effect or none at all (Carlson et al., 1987; Huang and Walters, 1992; Sun et al., 1993).

A number of electrophysiological, biochemical, and behavioral studies have shown that the expression of some DA effects requires activation of both D1- and D2-like receptors (e.g., Walters et al., 1987; White, 1987; Bordi and Meller, 1989; Wachtel et al., 1989; Bertorello et al., 1990). It is thus possible that the expression of the D1 feedback effect also requires concurrent activation of D2-like receptors. To test this hypothesis, we made extracellular recordings from SN DA neurons in a low cerveau isolé rat preparation and determined whether co-administration of a D2 agonist could enable a D1 agonist to produce an effect on DA cells.

Some results were reported previously in abstract form (Smith et al., 1994).

\section{MATERIALS AND METHODS}

Animal preparation. All procedures were performed in accordance with those outlined in the Guide for the Care and Use of Laboratory Animals published by the United States Public Health Service and approved by the Yale Animal Care and Use Committee. Male Sprague Dawley rats weighing between 160 and 300 gm were used. Previously, general anesthesia, including that induced by chloral hydrate, was shown to suppress the activity of striatal neurons (Kelland et al., 1988) and to block some DA receptor-mediated effects, including the D1 effect on nigral DA neurons in reserpinized animals and on subthalamic neurons (Huang and Walters, 1992; Kreiss et al., 1996). Because of this, most experiments were performed in a low cerveau isolé preparation. However, for comparison, a few experiments were performed in chloral hydrate- 
A

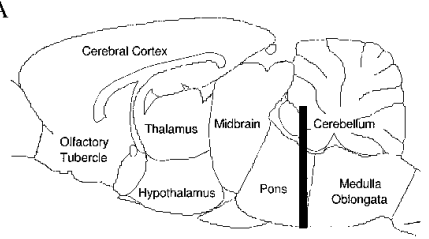

B

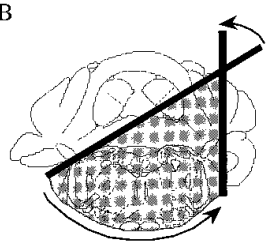

Figure 1. Diagram illustrating the position of brainstem transection for the low cerveau isolé preparation. $A$, Sagittal view of a rat brain showing the site of transection between the pons and the medulla oblongata ( $1 \mathrm{~mm}$ posterior to the lambda, indicated by the thick line). $B$, Coronal view of the transected areas (shaded) through the cerebellum and the brainstem. Thick lines illustrate the initial and final positions of the transection knife (a flattened needle). See Materials and Methods for details. Figures are redrawn from the rat atlas of Paxinos and Watson (1997).

anesthetized animals (400 mg/kg, i.p., with supplemental doses administered via the lateral tail vein). In the low cerveau isolé experiments, rats were initially anesthetized with halothane (Halocarbon Laboratories) and locally anesthetized by infiltration of the long-acting local anesthetic mepivacaine hydrochloride (2\%; Winthrop Pharmaceuticals) at all pressure points and incision sites. The brainstem was then transected using a method similar to that described previously (Sesack and Bunney, 1989). Briefly, a small burr hole was drilled $1 \mathrm{~mm}$ caudal to the lamboidal suture and $1 \mathrm{~mm}$ medial to the bony ridge at the lateral edge of the skull. A flattened 30 gauge, 0.5 inch needle was inserted at a $30^{\circ}$ angle relative to the cortical surface and rotated, parallel to the lamboidal suture, until the needle was at a $90^{\circ}$ angle (Fig. 1). Halothane anesthesia was discontinued for at least $30 \mathrm{~min}$ before beginning experiments. In all experiments body temperature was maintained at $35-38^{\circ} \mathrm{C}$ with a heating pad.

Electrophysiological recording. Single-unit activity of SN DA cells was recorded as described previously (Bunney et al., 1973; Grace and Bunney, 1980, 1983). Glass microelectrodes were made using a Narishige (Tokyo, Japan) electrode puller and filled with a $1 \mathrm{M} \mathrm{NaCl}$ solution containing $2 \%$ pontamine sky blue dye. The tip of the electrode was broken back under a microscope until a diameter of between 1 and 2 $\mu \mathrm{m}$ was obtained. The resistance of the electrode measured between 5 and $15 \mathrm{M} \Omega$. A small burr hole was drilled above the $\mathrm{SN}(3.0 \mathrm{~mm}$ anterior to the lamboidal suture and $2.0 \mathrm{~mm}$ lateral to the midline). The electrode was lowered $6.5-8.5 \mathrm{~mm}$ below the cortical surface. Electrical signals were amplified and sent to a personal computer (DECpc 450ST) via a Lab-PC ${ }^{+}$(National Instrument, Austin, Texas). Spike activity was continuously displayed on the computer screen. Interspike intervals and firing rate were collected on-line using software written by one of the authors (W.S.) using LabView (National Instrument). DA neurons were identified based on well established criteria (Bunney et al., 1973; Grace and Bunney, 1980, 1983). To allow histological examination of the recording site, a spot of dye was injected at the end of the recording by passing a $-30 \mu \mathrm{A}$ current through the electrode for $15-20 \mathrm{~min}$.

Drugs. Unless stated otherwise, most drugs were dissolved in distilled water and administered intravenously through the lateral tail vein. In some experiments, raclopride (RAC) was locally applied via a Hamilton 701 syringe $\left(1-5 \mu \mathrm{g} \cdot \mu \mathrm{l}^{-1} \cdot \mathrm{min}^{-1}\right.$ for $2 \mathrm{~min}$, controlled by a syringe pump) to the area slightly above the $\mathrm{SN}(6.0-6.5 \mathrm{~mm}$ below the cortical surface). To minimize the back flow, the syringe was removed $5 \mathrm{~min}$ after ejection. Drugs used in this study and their sources were SKF38393 hydrochloride [Research Biochemicals (RBI), Natick, MA], dyhydrexidine (DHX; Interneuron Pharmaceuticals, Lexington, MA), (+)SCH23390 hydrochloride (RBI), SCH39166 (Schering-Plough, Kenilworth, NJ), raclopride (Astra, Sodertalje, Sweden), quinpirole (Eli Lilly, Indianapolis, IN), and haloperidol (dissolved in a preprepared injection solution; McNeil Pharmaceuticals, Spring House, PA).

Statistics. The statistical significance of the effect of each drug was determined by comparing the firing rates (raw data, i.e., spikes/10 sec) before and after drug injection using a paired $t$ test. All numerical data were expressed as mean \pm SEM.

\section{RESULTS}

\section{Effect of D1 agonists alone on SN DA neurons}

In nine identified DA neurons, SKF38393 (10 mg/ $\mathrm{kg})$ was administered intravenously in either a single dose $(n=3)$ or multiple

doses (5 and $5 \mathrm{mg} / \mathrm{kg}, n=2$; or 2.5, 2.5, and $5 \mathrm{mg} / \mathrm{kg}, n=4$ ). Consistent with a previous study (Carlson et al., 1987), the D1 agonist failed to produce a consistent effect on DA cells. Five cells showed an increase in firing rate $(34.5 \pm 9.9 \%$ of baseline, ranging from 16.7 to $70.8 \%$ ), and four showed a decrease (42.7 \pm $19.2 \%$ of baseline, ranging from 18.2 to $100 \%$ ). To determine whether the effects of SKF38393 were mediated by D1-like receptors, the D1 antagonist SCH23390 $(20-100 \mu \mathrm{g} / \mathrm{kg})$ was administered after SKF38393 in five cells. In four cells, SCH23390 showed no effect on either SKF38393-induced excitation $(n=2)$ or inhibition $(n=2)$. In one cell, however, the inhibitory effect (18.2\% of baseline) of SKF38393 was reversed.

To test further whether the variable effect of SKF38393 is related to D1-like receptor stimulation, the new full D1 agonist DHX was administered to six other SN DA neurons $(1 \mathrm{mg} / \mathrm{kg}$ in a single dose). No significant change in the firing rate was observed in five of six cells ( $<10 \%$ change of baseline). In one cell, DHX produced an $18 \%$ inhibition of basal activity. Overall, the effect of DHX was statistically not significant $(4 \pm 3 \%$ decrease in baseline; $p=0.697 ; n=6$, paired $t$ test).

\section{Effect of D1 agonists on DA neurons pretreated with a D2 agonist}

To test whether activation of D2-like receptors is necessary for the expression of a D1 effect, nine DA cells were exposed to the D2-selective agonist quinpirole (administered i.v.) before the injection of SKF38393. Because quinpirole inhibits DA cells by itself, low doses $(11.7 \pm 2.2 \mu \mathrm{g} / \mathrm{kg}$, ranging from 5 to $20 \mu \mathrm{g} / \mathrm{kg})$ were injected to avoid a complete inhibition. In seven cells, SKF38393 (10 mg/kg, $n=6 ; 20 \mathrm{mg} / \mathrm{kg}, n=1)$, after quinpirole, produced no significant effect. Firing rate change after SKF38393 was indistinguishable from the spontaneous recovery (Fig. 2A,B). In the remaining two cells, SKF38393 $(10 \mathrm{mg} / \mathrm{kg}, n=1 ; 20$ $\mathrm{mg} / \mathrm{kg}, n=1)$ produced a clear further inhibition $(>10 \%$ of baseline). When the nine cells were combined, the firing rate was decreased from $56.5 \pm 7.3 \%$ of baseline immediately before SKF38393 to $52.8 \pm 9.4 \%$ at the maximum effect of SKF38393 (Fig. $2 A)$. This change was statistically not significant $(n=9 ; p=$ 0.757 , paired $t$ test).

However, it is possible that a D1 effect depends on activation of D2-like receptors located on DA target neurons rather than D2 autoreceptors. DA neurons are known to be more sensitive than DA target neurons to systemically administered DA agonists (Skirboll et al., 1979; White and Wang, 1986; Piercey et al., 1996a). The doses of quinpirole used in the above experiments may have been too low to activate D2-like receptors significantly on DA target neurons. To test this possibility, high doses of quinpirole were administered to 10 rats. To avoid a complete inhibition, doses of quinpirole were injected slowly at 3-10 min intervals (see Fig. 3B). Perhaps because of the development of tachyphalaxis of autoreceptors (Aghajanian and Bunney, 1973; Piercey et al., 1996a), DA cells remained active after a slow injection of 40-160 (92 \pm 15.8$) \mu \mathrm{g} / \mathrm{kg}$. In 9 of 10 cells, subsequent injection of SKF38393 $(5 \mathrm{mg} / \mathrm{kg}, n=1 ; 10 \mathrm{mg} / \mathrm{kg}, n=6 ; 20$ $\mathrm{mg} / \mathrm{kg}, n=2)$ produced a clear further inhibition $(>10 \%$ of baseline; Fig. $3 A, B)$. In the remaining one cell, SKF38393 (20 $\mathrm{mg} / \mathrm{kg}$ ) produced no significant effect. Overall, the firing rate was decreased by SKF38393 from $39.3 \pm 4.7$ to $10.9 \pm 4.1 \%$ of baseline $(p<0.0001 ; n=10$; paired $t$ test; Fig. $3 A, B)$. Unlike the inhibition induced by quinpirole alone, which was not affected at all by $\mathrm{SCH} 23390(160 \mu \mathrm{g} / \mathrm{kg} ; n=5$; Fig. $3 C)$, the inhibition 
A

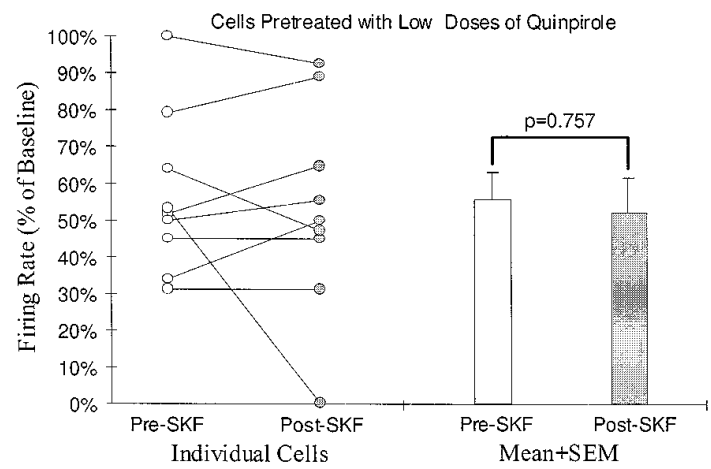

B

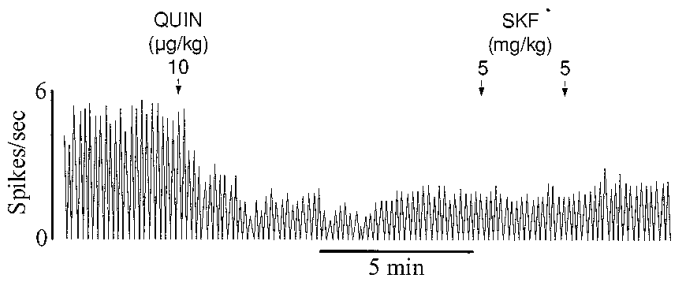

Figure 2. Systemic activation of D1-like receptors produces no consistent effect on the activity of SN DA cells in rats pretreated with low doses of a D2 agonist. $A$, Graph showing lack of a consistent effect of the D1 agonist SKF38393 on SN DA cells in rats pretreated with low doses of the D2 agonist quinpirole (5-20 $\mu \mathrm{g} / \mathrm{kg}$, i.v.). Open and filled circles represent, respectively, the firing rate of individual cells immediately before SKF38393 administration (10-20 mg/kg, i.v.) and after SKF38393 had produced a maximum effect. Straight lines link the data from individual cells. Of nine cells tested, seven were slightly excited or showed no response to SKF38393 $(<10 \%$ change in baseline) and two were inhibited. Overall, the firing rate was decreased nonsignificantly from $56.5 \pm$ 7.3 to $52.8 \pm 9.4 \%$ of baseline ( $p=0.757 ; n=9$; open and filed bars). $B$, Typical rate histogram showing lack of an effect of SKF38393 on the activity of an SN DA cell pretreated with a low dose of quinpirole. A single dose of quinpirole $(Q U I N, 10 \mu \mathrm{g} / \mathrm{kg}$, i.v.) inhibited the firing of the cell to $\sim 40 \%$ of baseline. Subsequent administration of SKF38393 (SKF $10 \mathrm{mg} / \mathrm{kg}$, i.v.) did not significantly affect the remaining activity. In this and following figures, arrows indicate the times of drug injection, and the numbers above the arrows represent the doses of the drug injected.

induced by SKF38393 was completely reversed by SCH23390 $(20-80 \mu \mathrm{g} / \mathrm{kg} ; n=6$; Fig. $3 B)$, confirming that it was a D1 effect.

To rule out the possibility that the slow speed of injection may play a role in the above observed enabling effect of quinpirole, a low dose of quinpirole $(10 \mu \mathrm{g} / \mathrm{kg})$ was administered slowly to five rats. In four of the five cells examined, SKF38393 $(10 \mathrm{mg} / \mathrm{kg})$ produced either no effect $(n=2)$ or a small increase in firing rate ( $n=2 ; 12.9$ and $13.9 \%$ of baseline, respectively). In one cell, SKF38393 inhibited the firing by $19 \%$ of baseline. Overall, the firing rate was not significantly changed (from $66.2 \pm 0.5$ to $66.7 \pm 0.1 \%$ of baseline; $n=5 ; p=0.93$, paired $t$ test), suggesting that it is the high dose rather than the slow speed of injection of quinpirole that enables the D1 agonist to inhibit DA cells.

\section{Effect of blockade of D2 autoreceptors on the D1 inhibition of DA neurons}

To test more directly the idea that the expression of the D1 effect does not require co-activation of DA autoreceptors, raclopride (2-8 $\mu \mathrm{g}$ ), a selective D2 antagonist, was locally applied to the SN 15 min before beginning recordings. In these locally treated cells, large doses of quinpirole (40 $\mu \mathrm{g} / \mathrm{kg}, n=6 ; 160 \mu \mathrm{g} / \mathrm{kg}, n=11 ; 640$ $\mu \mathrm{g} / \mathrm{kg}, n=1$ ) could be injected within a short period without
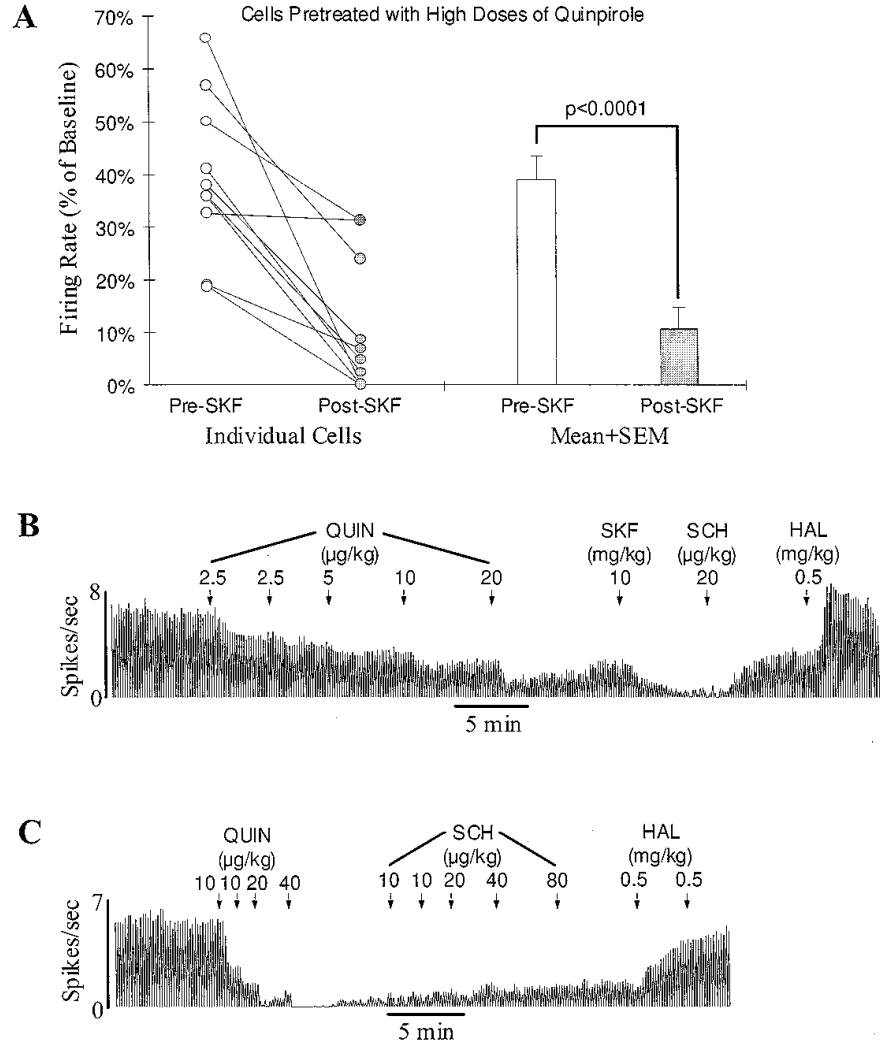

Figure 3. Systemic activation of D1-like receptors consistently inhibits SN DA neurons in rats pretreated with high doses of a D2 agonist. $A$, Graph showing the inhibition of DA cells by the D1 agonist SKF38393 $(5-20 \mathrm{mg} / \mathrm{kg}$, i.v.) in rats pretreated with high doses of the D2 agonist quinpirole (40-160 $\mu \mathrm{g} / \mathrm{kg}$, i.v.). Open and filled circles represent the firing rate of individual cells before and after SKF38393 injection, respectively. Of 10 cells tested, nine were inhibited, and one showed no response to SKF38393. On average, the firing rate was significantly decreased from $39.3 \pm 4.7$ to $10.9 \pm 4.1 \%$ of baseline $(p<0.0001 ; n=10$; open and filled bars). B. Typical rate histogram showing the inhibition by SKF38393 of a SN DA cell pretreated with a high dose of quinpirole $(Q U I N, 40 \mu \mathrm{g} / \mathrm{kg})$. After the final dose of quinpirole, the firing rate of this cell was decreased to about $40 \%$ of baseline. Subsequent administration of SKF38393 (SKF) almost completely stopped the remaining activity. The selective D1 antagonist $\mathrm{SCH} 23390(\mathrm{SCH})$ reversed the inhibition induced by SKF38393. Haloperidol $(H A L)$ further increased the firing rate to the predrug level. $C$, Typical rate histogram showing lack of an effect of the D1 antagonist SCH23390 on the inhibition induced by the D2 agonist quinpirole alone. After a cumulative dose of $80 \mu \mathrm{g} / \mathrm{kg}$, quinpirole $(Q U I N)$ completely inhibited the activity of this cell. About 2 min later, the cell began to recover spontaneously. SCH23390 (SCH), up to 160 $\mu \mathrm{g} / \mathrm{kg}$, produced no effect on the recovery of the cell. Haloperidol $(H A L)$, on the other hand, increased the activity to baseline.

completely inhibiting the cell. On average, the firing rate was inhibited by $47.9 \pm 5.1 \%$. In 17 of 18 cells tested, SKF38393 (5 $\mathrm{mg} / \mathrm{kg}, n=3 ; 7.5 \mathrm{mg} / \mathrm{kg}, n=1 ; 10 \mathrm{mg} / \mathrm{kg}, n=13 ; 20 \mathrm{mg} / \mathrm{kg}, n=$ 1) after quinpirole produced a clear further inhibition of firing ( $>10 \%$ of baseline; Fig. $4 A, B$ ). In the remaining one cell, the firing rate was reduced by $5 \%$. Overall, SKF38393 significantly decreased the firing rate from $47.9 \pm 5.1$ to $16.1 \pm 5.1 \%$ of baseline ( $n=18 ; p<0.0001$, paired $t$ test; Fig. $4 A$ ).

Similar experiments were performed in seven other locally raclopride-treated $(4-10 \mu \mathrm{g})$ DA cells, in which SKF38393 was replaced with DHX $(0.5 \mathrm{mg} / \mathrm{kg}, n=3 ; 0.75 \mathrm{mg} / \mathrm{kg}, n=1 ; 1$ $\mathrm{mg} / \mathrm{kg}, n=3)$. After pretreatment with quinpirole $(160 \mu \mathrm{g} / \mathrm{kg})$, 


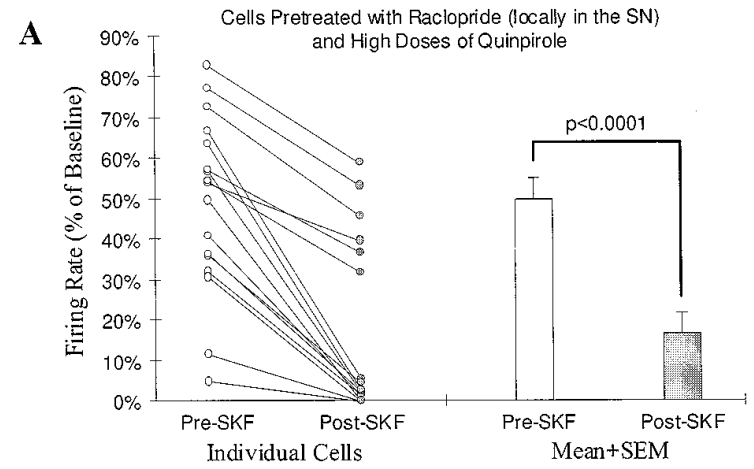

B

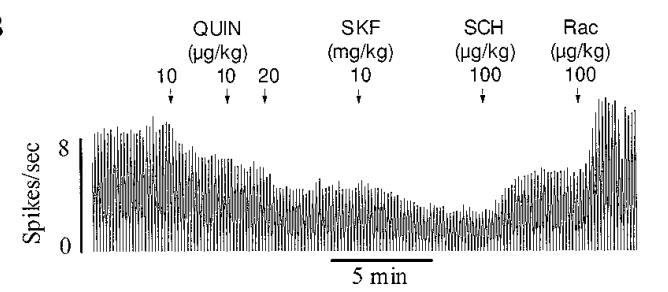

Figure 4. D1-mediated feedback inhibition persists after DA autoreceptors are blocked. $A$, Graph showing inhibition by the D1 agonist SKF38393 of DA cells with blocked DA autoreceptors. Before testing for the D1 response, raclopride was introduced locally just above the SN (2-8 $\mu \mathrm{g})$ to block DA autoreceptors, and high doses of quinpirole (40-640 $\mu \mathrm{g} / \mathrm{kg}$, i.v.) were administered to activate D2-like receptors on DA target neurons. Open and filled circles represent the firing rate of individual cells before and after SKF38393 injection (5-10 mg/kg, i.v.), respectively. In 17 of 18 cells, SKF 38393 produced a clear further inhibition. On average, the firing rate was reduced significantly from $47.9 \pm 5.1$ to $16.1 \pm 5.1 \%$ of baseline (open and filled bars; $p<0.0001 ; n=18$ ). B. Typical rate histogram showing the inhibition by SKF38393 of an SN DA cell treated locally with raclopride $(8 \mu \mathrm{g})$. A cumulative dose of $40 \mu \mathrm{g} / \mathrm{kg}$ of quinpirole $(Q U I N)$ produced a $50 \%$ inhibition of firing. Injection of SKF38393 $(S K F)$ produced a clear further inhibition. The D1 antagonist SCH39166 $(\mathrm{SCH})$ reversed the inhibition induced by SKF38393. The D2 antagonist raclopride $(R a c)$ brought the activity back to baseline.

DHX produced a clear inhibition in all seven cells (from $45.0 \pm$ 7.0 to $13.8 \pm 4.1 \%$ of baseline; $p<0.001$, paired $t$ test; Fig. 5).

\section{Effect of chloral hydrate on D1-mediated inhibition of DA neurons}

Some D1-mediated effects have been shown to be blocked by the commonly used anesthetic chloral hydrate (Huang and Walters, 1992; Kreiss et al., 1996). To determine whether the D1 inhibition observed in the present study shares a similar property, the effect of SKF38393 was reexamined in animals treated with chloral hydrate. Seven animals were anesthetized with chloral hydrate (400 mg/kg, i.p.). To be sure that transection did not affect the result, four of the animals also had their brainstems transected. Because animals in the latter group did not breathe spontaneously, artificial respiration was performed. The respiration rate was adjusted to maintain an expired $\mathrm{CO}_{2}$ level of $3.5-4.5 \%$ as measured by a $\mathrm{CO}_{2}$ analyzer. No difference was found between the results obtained from the two groups. Thus, in all animals treated with chloral hydrate, pretreatment with quinpirole (40 $\mu \mathrm{g} / \mathrm{kg}, n=3 ; 80 \mu \mathrm{g} / \mathrm{kg}, n=3 ; 160 \mu \mathrm{g} / \mathrm{kg}, n=1$, injected slowly as described above; see Fig. $3 B$ ) failed to enable SKF38393 $(10-20 \mathrm{mg} / \mathrm{kg}$ ) to produce any further inhibition (Fig. 6).
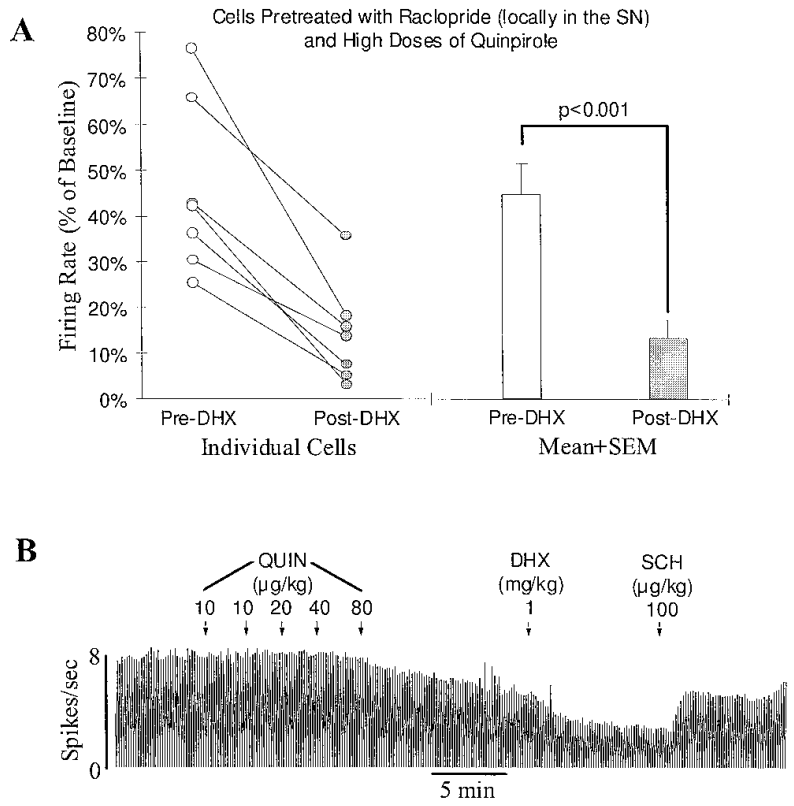

Figure 5. The new D1 agonist DHX mimics the effect of SKF38393 and inhibits the activity of DA cells treated with high doses of the D2 agonist quinpirole. $A$, Graph showing the inhibition induced by DHX (0.5-1 $\mathrm{mg} / \mathrm{kg}$ ) of seven SN DA cells in rats pretreated with raclopride $(4-10 \mu \mathrm{g}$, locally in the SN) and with quinpirole $(160 \mu \mathrm{g} / \mathrm{kg}$, i.v.). Open and filled circles represent the firing rate of individual cells before and after DHX injection, respectively. All cells showed an inhibitory response to DHX. On average, the firing rate was reduced from $45.0 \pm 7.0$ to $13.8 \pm 4.1 \%$ of baseline (open and filled bars; $p<0.001$ ). B. Typical rate histogram showing the inhibition by DHX of an SN DA cell pretreated locally with raclopride $(10 \mu \mathrm{g})$. Quinpirole $(Q U I N, 160 \mu \mathrm{g} / \mathrm{kg})$ inhibited the firing rate of this cell to $65 \%$ of baseline. DHX further inhibited the activity to $35 \%$. SCH39166 ( $\mathrm{SCH})$ reversed the inhibition induced by DHX. Raclopride further returned the activity to predrug baseline (data not shown).

\section{DISCUSSION}

The present study suggests that feedback control of DA neurons involves not only D2- but also D1-like receptors. However, the D1-mediated feedback inhibition requires co-activation of D2like receptors to be expressed and is blocked completely by a commonly used anesthetic, chloral hydrate.

\section{D1 agonists alone produce variable or no effects on the spontaneous activity of DA neurons}

Consistent with a previous study in a locally anesthetized, paralyzed preparation (Carlson et al., 1987), our study shows that systemically administered SKF38393 produces variable effects on SN DA neurons. However, two other similar studies showed no effect of SKF38393 on SN DA cells (Huang and Walters, 1992; Sun et al., 1993). The cause for the discrepancy in findings is unknown. However, if SKF38393 alone has an effect, the effect may not be mediated by D1-like receptors. The present study shows that the effect induced by SKF38393 alone was not reversed by the D1 antagonist SCH23390 in most cells examined and not mimicked by the full D1 agonist DHX.

In chloral hydrate-anesthetized animals, SKF38393 was reported to have no effect on the firing rate of DA cells. However, it modulates the D2 response (Kelland et al., 1988). In control animals, the ability of the D2 agonist quinpirole to inhibit DA cells is negatively correlated with their basal firing rate. Pretreatment with SKF38393 eliminated the rate depen- 
A

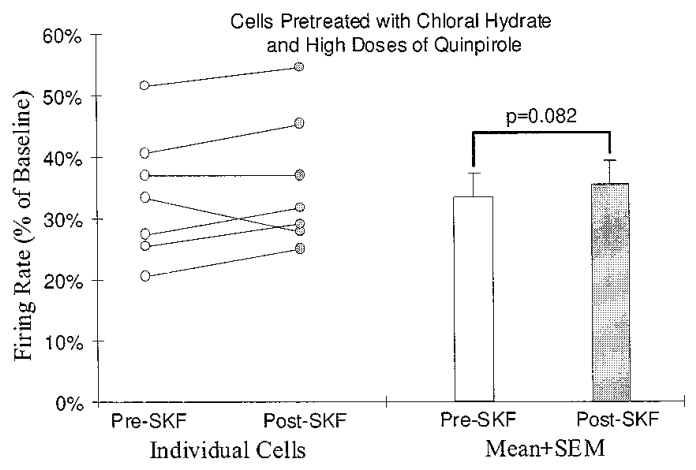

B

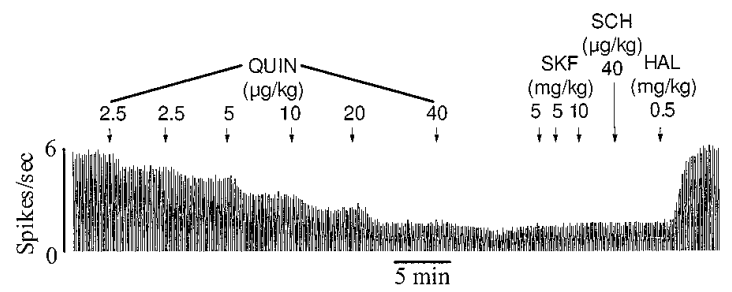

Figure 6. The anesthetic chloral hydrate blocks the D1-mediated feedback inhibition of SN DA neurons. $A$, Graph showing lack of an effect of a D1 agonist on SN DA cells in chloral hydrate-anesthetized animals (400 $\mathrm{mg} / \mathrm{kg}$, i.p.). Before testing for the effect of SKF38393, rats were pretreated with a high dose of quinpirole ( $40-160 \mu \mathrm{g} / \mathrm{kg}$, i.v.). Open and filled circles represent the firing rate of individual cells before and after SKF38393 injection $(10-20 \mathrm{mg} / \mathrm{kg}$, i.v.), respectively. No significant D1 effect was observed in any of the seven cells tested. The average firing rate of the cells was slightly increased from $33.7 \pm 4.0$ to $35.8 \pm 4.0 \%$ of baseline after SKF38393 injection (open and filled bars; $p=0.082$ ). $B$ Typical rate histogram showing lack of an effect of SKF38393 $(20 \mathrm{mg} / \mathrm{kg})$ on an SN DA cell in a chloral hydrate-anesthetized animal $(400 \mathrm{mg} / \mathrm{kg}$, i.p.). The firing rate of the cell was reduced to about $30 \%$ of baseline after a high dose of quinpirole (QUIN, $80 \mu \mathrm{g} / \mathrm{kg}$, i.v.). Subsequent administration of SKF38393 $(S K F)$ and SCH23390 $(S C H)$ produced no effect on the remaining activity. Haloperidol $(H A L)$ returned the firing rate to baseline.

dency of the $\mathrm{D} 2$ inhibition, suggesting a modulatory role of the D1 feedback pathway. However, as will be discussed, the D1 pathway, under certain conditions, also has an inhibitory effect on DA neurons.

\section{Co-activation of D2-like receptors enables a D1 agonist to inhibit DA neurons}

It is well known that the expression of some DA effects requires co-activation of D1- and D2-like receptors (Walters et al., 1987; White, 1987; Bordi and Meller, 1989; Wachtel et al., 1989; Bertorello et al., 1990). The present study suggests that a similar D1-D2 interdependency is involved in feedback control of DA neurons. Our data showed that the D1 agonists SKF38393 and DHX, although having no effect or producing a variable response in control animals, consistently inhibited DA cells in animals pretreated with high doses of the D2 agonist quinpirole.

The proposed D1-D2 interaction may also explain why a D1 agonist is capable of inhibiting DA neurons in reserpine-treated animals (Huang and Walters, 1992; Sun et al., 1993). Chronic treatment with reserpine is known to cause a breakdown of D1-D2 interdependency. As a result, activation of either receptor alone can produce an effect that, otherwise, can only be observed when both D1- and D2-like receptors are activated (e.g., Arnt, 1985; LaHoste et al., 1996). Although the underlying mechanism for this action of reserpine remains unclear, it is possible that reserpine treatment also interrupts D1-D2 interaction in feedback control of DA cells so that a D1 agonist alone can produce an inhibition of DA cells (Huang and Walters, 1992; Sun et al., 1993).

\section{D1-mediated feedback inhibition requires co-activation of D2-like receptors on DA target neurons, rather than DA neurons themselves}

D2-like receptors are present on both DA neurons (DA autoreceptors) and DA target neurons. Both receptors could be activated by systemically administered quinpirole, and both may play a role in enabling the D1 effect. Our results suggest, however, that the D1-mediated feedback inhibition does not require activation of DA autoreceptors. In the initial experiments, animals were pretreated with only low doses of quinpirole $(\leq 20 \mu \mathrm{g} / \mathrm{kg})$. Although quinpirole produced a significant inhibition in these experiments, no further effect of SKF38393 was observed. Because a low dose of a D2 agonist acts preferentially on DA neurons (Skirboll et al., 1979; White and Wang, 1986; Piercey et al., 1996a), these results provided the first evidence suggesting that the expression of the D1 effect may not depend on activation of DA autoreceptors. In the second set of experiments, animals were pretreated with high doses of quinpirole. However, quinpirole had to be injected slowly to avoid a complete inhibition of DA cells. Although SKF38393 produced a clear inhibition in these cells, it was difficult to determine whether it was the dose of quinpirole injected, the speed of injection, or the degree of inhibition induced by high doses of quinpirole that modified the response of the cell to a D1 agonist. To rule out the possibility that the slow injection may play a role, animals were given, slowly, a low dose of quinpirole $(10 \mu \mathrm{g} / \mathrm{kg})$. In four of five cells tested, SKF38393 failed to produce a clear effect, suggesting that the kinetics of injection of quinpirole is not a critical factor in the emergence of the D1 effect. To test more directly whether activation of DA autoreceptors is needed for the expression of D1 inhibition, raclopride was applied locally to the SN to block DA autoreceptors. In these experiments, DA cells remained active even after a fast injection of a large dose of quinpirole. Although the degree of inhibition induced by quinpirole was less compared with that seen in the second set of experiments, SKF38393 produced an even greater inhibition (see Figs. 3, 4). Thus, neither the speed of quinpirole injection nor the degree of inhibition induced by quinpirole seems to play a role in the observed D1 inhibition. By demonstrating a D1 effect even after autoreceptors were blocked, this last set of experiments provided more direct evidence suggesting that D2-like receptors on DA target neurons are more important in determining the expression of the D1 feedback inhibition.

Clearly, further experiments are needed to pinpoint where exactly D1 and D2 agonists may interact to regulate the activity of DA cells. With the data available, particularly from anatomical studies (see the introductory remarks), one may speculate that striatonigral GABA neurons may play a key role. D1-like receptors are found on both their cell bodies in the striatum and their terminals in the SN. An in vitro study showed that activation of D1-like receptors on GABAergic terminals in the ventral tegmental area increases $\mathrm{GABA}_{\mathrm{B}}$ receptor-mediated GABA input to DA neurons (Cameron and Williams, 1993). Whether this is also the case in the SN has not been determined. An in vivo study in reserpinized animals suggests, however, that systemically admin- 
istered SKF38393 may act mainly in the striatum to inhibit DA neurons (Sun et al., 1996).

A D2 agonist may act directly on the same striatonigral neurons to modulate the D1 effect, if D1- and D2-like receptors colocalize in these cells (Lester et al., 1993; Surmeier et al., 1993, 1996). Alternatively, D2 agonists may act on a different population of striatal or nonstriatal neurons to modulate D1-mediated feedback pathways indirectly. Previously, systemic administration of the D2 agonist quinpirole was shown to increase the activity of some striatal neurons (at doses higher than those needed to inhibit DA cells; Piercey et al., 1996b). The D1 agonist SKF38393 alone, on the other hand, produced only a small or no effect (Piercey et al., 1996b). Although it is unclear how the D2 excitatory effect is produced, a recent in vitro study suggests that during D2-induced excitation, a D1 agonist may become capable of further increasing the activity of striatal neurons (Hernandezlopez et al., 1997). If, under such conditions, striatonigral neurons are among the cells that are further excited by the D1 agonist, this D1-mediated excitation in the striatum would be translated into an inhibition of nigral DA neurons. Further experiments are needed to determine whether this hypothesis is correct.

\section{Clinical speculations}

The involvement of both D1- and D2-like receptors in feedback control of DA neurons could have significant clinical implications if drugs selective for DA receptor subtypes were used for treating disorders such as schizophrenia, Parkinson's disease, and substance abuse. Because of the presence of feedback pathways, these drugs may produce unexpected results. For example, a D2-selective agonist may be used for treating Parkinson's disease. However, at low doses, D2 agonists may act preferentially on D2 autoreceptors to inhibit the activity of the remaining DA cells and their release and, thus, exacerbate the symptoms. Although at high doses a D2 agonist may act postsynaptically to increase D2 receptor-mediated function, the residual D1 function, mediated by endogenously released DA, may become further reduced because of the D2-mediated feedback inhibition. Our data suggest that a D1 agonist may lead to a similar reduction in the availability of endogenous DA for action at D2-like receptors.

Most antipsychotic drugs are D2 antagonists. These drugs are known to block feedback inhibition and to increase DA cell activity and DA release. If an antipsychotic drug blocks only D2 receptors, the increased DA release would lead to a selective stimulation of D1 receptors. Similarly, a selective D1 antagonist may increase the availability of endogenous DA for action at D2-like receptors. Although remaining to be verified, the proposed feedback pathway-mediated effects may contribute to the clinical effects of current drugs acting on DA systems.

\section{REFERENCES}

Aghajanian GK, Bunney BS (1973) Central dopaminergic neurons: neurophysiological identification and responses to drugs. In: Frontiers in catecholamine research (Usdin E, Snyder SH, eds), pp 643-648. New York: Pergamon.

Arnt J (1985) Behavioural stimulation is induced by separate dopamine D-1 and D-2 receptor sites in reserpine-pretreated but not in normal rats. Eur J Pharmacol 113:79-88.

Bertorello AM, Hopfield JF, Aperia A, Greengard P (1990) Inhibition by dopamine of $(\mathrm{Na}(+)+\mathrm{K}+)$ ATPase activity in neostriatal neurons through D1 and D2 dopamine receptor synergism. Nature 347:386-388.

Bolam JP, Smith Y (1990) The GABA and substance P input to dopaminergic neurones in the substantia nigra of the rat. Brain Res 529:57-78.

Bordi F, Meller E (1989) Enhanced behavioral stereotypies elicited by intrastriatal injection D1 and D2 dopamine agonists in intact rats. Brain Res 504:276-283.
Bunney BS, Aghajanian GK (1976a) The precise localization of nigral afferents in the rat as determined by a retrograde tracing technique. Brain Res 117:423-435.

Bunney BS, Aghajanian GK (1976b) D-Amphetamine-induced inhibition of central dopaminergic neurons: mediation by a striato-nigral feedback pathway. Science 192:391-393.

Bunney BS, Aghajanian GK (1978) D-Amphetamine-induced depression of central dopamine neurons: evidence for mediation by both autoreceptors and a striato-nigral feedback pathway. Naunyn Schmiedebergs Arch Pharmacol 304:255-261.

Bunney BS, Walters JR, Roth RH, Aghajanian GK (1973) Dopaminergic neurons: effect of antipsychotic drugs and amphetamine on single cell activity. J Pharmacol Exp Ther 185:560-571.

Caille I, Dumartin B, Bloch B (1996) Ultrastructural localization of d1 dopamine receptor immunoreactivity in rat striatonigral neurons and its relation with dopaminergic innervation. Brain Res 730:17-31.

Cameron DL, Williams JT (1993) Dopamine D1 receptors facilitate transmitter release. Nature 366:344-347.

Carlson JH, Bergstrom DA, Weick BG, Walters JR (1987) Neurophysiological investigation of effects of the D-1 agonist SKF 38393 on tonic activity of substantia nigra dopamine neurons. Synapse 1:411-416.

Freund TF, Powell JF, Smith AD (1984) Tyrosine hydroxylaseimmunoreactive boutons in synaptic contact with identified striatonigral neurons, with particular reference to dendritic spines. Neuroscience 13:1189-1215.

Grace AA, Bunney BS (1980) Nigral dopamine neurons: intracellular recording and identification with L-dopa injection and histofluorescence. Science 210:654-656.

Grace AA, Bunney BS (1983) Intracellular and extracellular electrophysiology of nigral dopaminergic neurons-1. Identification and characterization. Neuroscience 10:301-315.

Hernandezlopez S, Bargas J, Surmeier DJ, Reyes A, Galarraga E (1997) $\mathrm{D}-1$ receptor activation enhances evoked discharge in neostriatal medium spiny neurons by modulating an L-type $\mathrm{Ca}^{2+}$ conductance. J Neurosci 17:3334-3342.

Huang KX, Walters JR (1992) D1 receptor stimulation inhibits dopamine cell activity after reserpine treatment but not after chronic SCH 23390: an effect blocked by $N$-methyl-D-aspartate antagonists. J Pharmacol Exp Ther 260:409-416.

Kelland MD, Freeman AS, Chiodo LA (1988) SKF 38393 alters the rate-dependent D2-mediated inhibition of nigrostriatal but not mesoaccumbens dopamine neurons. Synapse 2:416-423.

Kreiss DS, Anderson LA, Walters JR (1996) Apomorphine and dopamine $\mathrm{D}(1)$ receptor agonists increase the firing rates of subthalamic nucleus neurons. Neuroscience 72:863-876.

LaHoste GJ, Ruskin DN, Marshall JF (1996) Cerebrocortical Fos expression following dopaminergic stimulation: D1/D2 synergism and its breakdown. Brain Res 728:97-104.

Lester J, Fink S, Aronin N, DiFiglia M (1993) Colocalization of D1 and D2 dopamine receptor mRNAs in striatal neurons. Brain Res 621:106-110.

Nitsch C, Riesenberg R (1988) Immunocytochemical demonstration of GABAergic synaptic connections in rat substantia nigra after different lesions of the striatonigral projection. Brain Res 461:127-142.

Paxinos G, Watson C (1997) The rat brain. San Diego: Academic.

Piercey MF, Hoffmann WE, Smith MW, Hyslop DK (1996a) Inhibition of dopamine neuron firing by pramipexole, a dopamine D3 receptorpreferring agonist: comparison to other dopamine receptor agonists. Eur J Pharmacol 312:35-44.

Piercey MF, Hyslop DK, Hoffmann WE (1996b) Excitation of type II caudate neurons by systemic administration of dopamine agonists. Brain Res 706:249-258.

Sesack SR, Bunney BS (1989) Pharmacological characterization of the receptor mediating electrophysiological responses to dopamine in the rat medial prefrontal cortex: a microiontophoretic study. J Pharmacol Exp Ther 248:1323-1333.

Skirboll LR, Grace AA, Bunney BS (1979) Dopamine auto- and postsynaptic receptors: electrophysiological evidence for differential sensitivity to dopamine agonists. Science 206:80-82.

Smith P, Shi WX, Bunney B (1994) D1 receptor-mediated inhibition of midbrain DA neurons requires co-activation of postsynaptic D2 receptors. Soc Neurosci Abstr 20:1354.

Sun BC, Huang KX, Jin GZ (1993) Repeated reserpine treatment alters firing pattern and responses of substantia nigral dopamine neurons. Eur J Pharmacol 231:331-338. 
Sun BC, Chouvet G, Jin GZ (1996) D-1 dopamine receptor stimulation inhibits firing activity of midbrain dopamine neurons in reserpine treated rats-an effect eliminated after hemitransection of diencephalon. Synapse 24:29-38.

Surmeier DJ, Reiner A, Levine MS, Ariano MA (1993) Are neostriatal dopamine receptors co-localized? Trends Neurosci 16:299-305.

Surmeier DJ, Song WJ, Yan Z (1996) Coordinated expression of dopamine receptors in neostriatal medium spiny neurons. J Neurosci 16:6579-6591.

Wachtel SR, Hu XT, Galloway MP, White FJ (1989) D1 dopamine receptor stimulation enables the postsynaptic, but not autoreceptor, effects of D2 dopamine agonists in nigrostriatal and mesoaccumbens dopamine systems. Synapse 4:327-346.
Walters JR, Bergstrom DA, Carlson JH, Chase TN, Braun AR (1987) D1 dopamine receptor activation required for postsynaptic expression of D2 agonist effects. Science 236:719-722.

White FJ (1987) D-1 dopamine receptor stimulation enables the inhibition of nucleus accumbens neurons by a D-2 receptor agonist. Eur J Pharmacol 135:101-105.

White FJ, Wang RY (1986) Electrophysiological evidence for the existence of both D-1 and D-2 dopamine receptors in the rat nucleus accumbens. J Neurosci 6:274-280.

Yung KK, Bolam JP, Smith AD, Hersch SM, Ciliax BJ, Levey AI (1995) Immunocytochemical localization of D1 and D2 dopamine receptors in the basal ganglia of the rat: light and electron microscopy. Neuroscience 65:709-730. 